\title{
Unresectable Malignant Solid Neoplasm
}

National Cancer Institute

\section{Source}

National Cancer Institute. Unresectable Malignant Solid Neoplasm. NCI Thesaurus. Code C148036.

A malignant solid neoplasm that is not amenable to surgical resection. 